\title{
槌趾に対する長母指屈筋腱延長術について
}

九州厚生年金病院整形外科

$\begin{array}{cccc}\text { 杉 } & \text { 山 } & \text { 栄 } & \text { 一 } \\ \text { 喜 } & \text { 多 } & \text { 正 } & \text { 鎮 } \\ \text { 野 } & \text { 副 } & & \text { 勝 }\end{array}$

\section{The Lengthening of Flexor Hallucis Longus Tendon for Claw Toes}

\author{
By \\ E. Sugiyama, M. Kita \& M. Nozoe \\ Department of Orthopedic Surgery Kyushu Welfare \\ Pension Hospital
}

\begin{abstract}
A school boy aged seventeen years sustained a open fracture of right tibial and fibular shaft in a motorcycle accident.

He had marked swelling of the injured leg and loss of sensation in right foot.

When the plaster was removed a month later, he noticed equino-varus deformity of right ankle and clawed deformity of right toes.

We repaired the clawed deformities of the hallux and other toes by the lengthening of the flexor hallucis longus tendon.

The slip between the flexor hallucis longus and flexor digitorum longus tendon was confirmed anatomically.

We think the lengthening of the flexor hallucis longus tendon is a excellent treatment for the claw toe deformity which was not caused by paralysis of the intrinsic muscles.
\end{abstract}

脛骨々幹部骨折後に尖足，足関節内反および槌趾変 形を来すことを時々経験する．割合治療を受けずに放 置されることが多く，また徒手矯正その他かなり長期 間保存的治療を行なってあ変形が残り, 歩行障害, DIP 関節背側, MP 関節底側の疼痛等を来し, 患者 の苦痛は大きい, 種々の手術書に関節固定術, 腱移行 術等の記載があるが, 最近, 松井等が長母指屈筋腱の 延長術を行ない第 1,2 趾の槌趾変形を治療させた報 告があるので, 我々も第 $1 \sim 4$ 趾の高度の槌趾変形に 対してれを行なってみた. その結果を報告し, 併せて 脛骨々折後の槌趾変形の原因, 長母指屈筋腱之長指屈 筋腱間の slip 等について考察を加えてみた.

症例 117 才男子.

昭和 45 年 10 月 30 日バイク運転中, 軽四輪之衝突 し転倒. 右下腿骨開放骨折にて某医で直ちに骨接合術 を受けギプス包帯を1力月間行なった，手術直後より 右下腿以下に高度の腫脹を来し, 下腿以下にじんじん した感じがあったがそのままにして，1 カ月後，ギプ
スを除去した. その頃より右足関節背屈障害, 第 1 4 趾の槌趾変形, 足関節内反変形に気付き約 2 力月間 徒手矯正を行なったが軽快せず, 2 月 18 日当科入院.

入院時所見: 右下腿中下 $1 / 3$ 付近の皮䖈に手術後洀 痕および皮膚のやや陥凹を認め, 右足関節は尖足位お よび軽度内反位を保ち足関節背屆は制限され，第 1 4 趾の MP 関節過伸展位, PIP 関節屈曲位を保って いる. 槌趾変形は 1，2，3 趾汇著明である. 右足関節 以下に知覚鈍麻を訴え, 右足背動脈は触れるが健例に 比して弱い.MP 関節における屈曲力はやや低下して いるが，かなり力は保たれている.

レ線所見では中下 $1 / 3$ にて脛骨, 腓骨々折があるが すでに骨療合し，筋電図所見で母指外転筋，短指屈筋 に多数の Reinnervation Voltage が見られ，後脛骨 筋, 長母指屈筋および辰指屈筋に筋原性萎縮の所見が 見られた。

手術所見: 右脛骨踝の後方に弓状切開を加え後脛骨 筋, 長指屈筋腱を前方へよけ長母指屈筋腱を出す. こ 

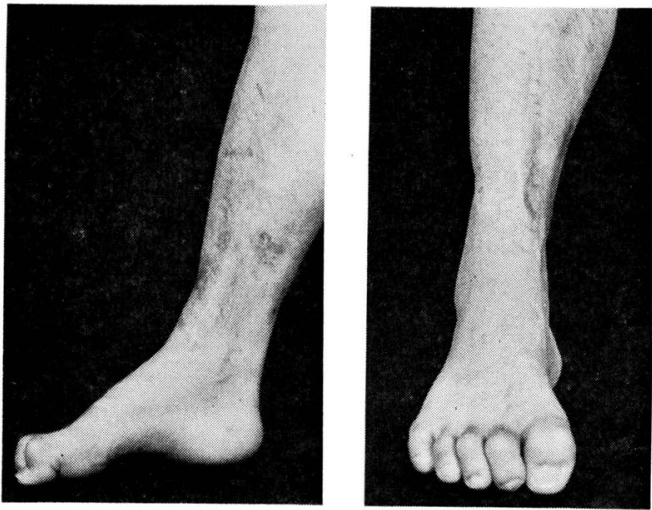

図1 手 術 前
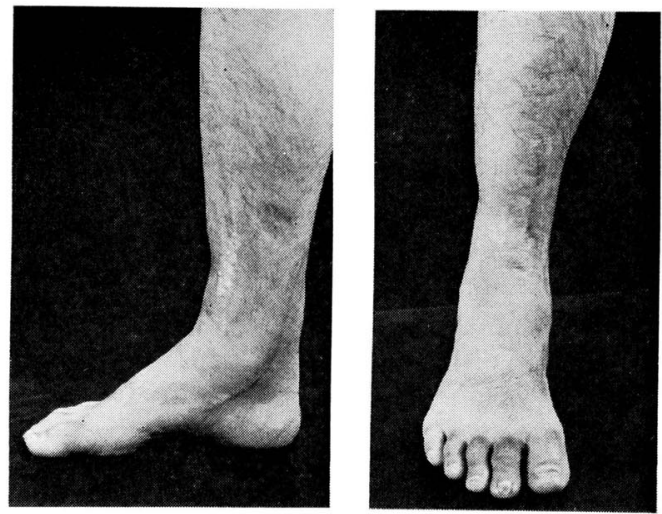

図2 手術後

れを緊張さすと第 1 ～4 趾共に屈曲を来し，乙の腱を $Z$ 状に切離すると母指 IP 関節， $2 \sim 4$ 趾の PIP 関 節伸展が容易となった。同特に皮膚切開を延長し，ア キレス腱延長術，足関節後方関節包切開を行ない尖足 を出来るだけ矯正し，その後，长母指屈筋腱の延長を 約 $2 \mathrm{~cm}$ 行ない手術を終った.

術後ギプス包帯を行ない後療法はアキレス腱縫合術 に準じた。

手術後, 母趾の変形はよく短正されている. 第 2 4 趾も術前に比し非常によくなっているが, 足関節背 屆は 95 度まででまだ完全に回復していない，MP 関 節におけるる屈曲力は結構保たれているので歩行の際跛 行は見られず, 疼痛むないが, 足関節背屈障害のため 自動車の運転特アクセルを踏むとき少し調子が悪いと 訴えている.

症例 215 才男子.

野球をしていて転倒し左下腿骨々折を抏てし某医に
入院. 骨接合術を受け, 膝下より足尖までギプス固定 を 1 カ月間行なった．受伤直後より腓腹部以下にじん じんした感じがあり，腫脹が著明でギプスを除去した 頃に尖足, 槌趾変形, 足関節内反変形に気付き, 変形 は次第に増強したという，当科入院後手術を行なっ た． 先ず下腿中央後方より脛骨神経㑢す，周囲の軟 部組織汢色が悪々洀痕状態となり，脛骨神経は広範に 周囲上瘾着を認め, 神経そのものの損㑺はなかったの で神経剝離術を行なった．数週後, 足底腱膜を切開し 長母指屈筋腱 および 長指屈筋腱を出し, 両腱を約 1 $\mathrm{cm}$ 延長. 一応㮸趾変形はある程度矯正されたが，ギ プス 1 力月間固定後やはり変形が残ったので, 腱癒着 を考え再度癒着剥離を行なったが第1例はよ゙は良い結 果を得なかった．足底部にては 周囲と癒着が起り易 々, 手術操作自体む困難なため内踝後方で腱延長を行 なった方がよいと思われる.

\section{長母指屈筋腱と長指屈筋腱間の slip について}

29 才 男子. 急性黄色肝萎縮にて死亡した新鮮屍体 にて解剖を行なった。 足底腱膜と短母指屈筋を反転 す. 長母指屈筋腱は長指屈筋腱の深部を通り交叉して 足底部中央にて母指側に出てやや外側よりもう 1 本枝 を出し，これが約 $5 \mathrm{~cm}$ 斜めに走った後やや幅広扇 形になり，屒指屈筋腱と重なり第 $2 \sim 4$ 指に同時につ いている如く見られた．長母指屈筋腱の劧引にて第 1 〜 4 趾まで同時に屈曲するのが認められた.

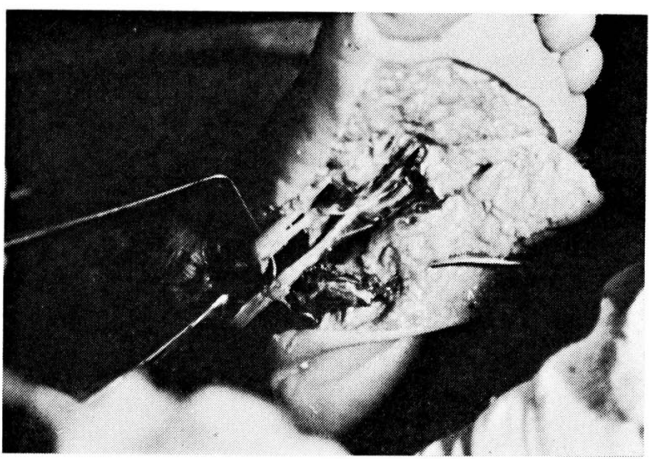

図3長母指屈筋腱及び長指屈筋腱に筋 鈎をかけている。長母指屈筋腱よ り枝が分れ未梢部で長指屈筋腱へ 結合している。

考

察

E1lis 等は 1958 年 235 例の脛骨々幹部骨折について 
調查した結果，21 例に足関節および足の変形を来し， そのうち 7 例は明らかに阻血性拘縮によると述べてい る. 彼は下腿の血行障害により腓腹部の軟部組織に壊 死が扣こり, その結果, 尖足, 足関節内反, 槌趾変形 等在来すと記載している，1967 年 Owen 等は脛骨々 折後の阻血性拘縮について解剖学的に, 下腿中央にて 脛骨後面之血管が非常に近くにあり，乙れに反し前方 の血管は，かなり離れているため下腿中央にて腓腹部 の筋がよく冒されると述べ，筋電罒所見として短指屈 筋, 拇指外転筋の Denervation が見られ，腓腹筋の Activity の低下が見られ伸展筋は全く正常だったと 記載している. Thomson \& Mahoney は大腿骨々折 後の阻血拘縮について記載しており,やはり腓腹部の 軟部組織に阻血がおこり，その結果 Fibrosis がおこ り足の変形を来すといっている．また Thomas 等は 健康は下肢の固定のみでは重篤な関節拘縮は来さない と述べている. 1944 年 McKeever は脛骨々折後, 長母指屈筋が仮骨と癒着をおこし, その結果母趾の槌 趾変形を来すと述へ，乙れを Checkrein Deformity と名付け記載している. 1971 年松井等は下腿挫傷後 の第 1,2 趾の桘趾変形に 対し 長母指屈筋腱延長術を 行ない, 乙れは出血等による癒着のために起ったもの であろうと述べている. 脛骨々折後, 阻血性拘縮また は仮骨, 出血による偣着等により桘趾変形が起り得る が, 症状の程度, 範囲等により判別可能で, 我々の症 例は阻血性拘縮が主な原因であろうと考えられる。

槌趾変形に対する手術療法については Young 法 などの PIP 関節固定術, Dickson \& Diverley また は Robert Jones 等の PIP 関節固定術プラス伸筋腱 の屈筋腱への移行術, Tayler 等の屈筋の绅筋腱への 移行術等種々あるが, 症例に応じて選択すべきであ る. しかし, 我々の症例の如く早期に長母指屈筋腱の 延長術を行なうのみで割合容易に治癒することがあ る. 一般に claw toe 変形は intrinsic muscle の麻 疸, 筋力低下により起ることが多く, この場合は腱移 行術等行なっててれを補なわなければならない.しか し，虫様筋，骨間筋の筋力が保にれ指関節の拘縮がま だ起っていなくて，まだ可動性のある症例には長母指 屈筋腱の延長術は非常に簡単で, 効果的である.

\section{結語}

我々は脛骨々折後の槌趾変形に対し長母指屈筋腱延 長術を行ない良い結果を得たので，乙れについて解剖
学的所見, 脛骨々折後の槌趾変形の原因, 手術法等に ついて検討を加えた。

$$
\text { 文献 }
$$

1）松井 猛 - 他：長田指屈筋之長指屈筋間の腱性 結合について. 整形外科 22慈 228, 1971.

2) H, Ellis. : Disability after tibial shaft fractures. J.B.J.S. Vol. 40-B, 190, 1958.

3) Staut A, Thomson etc. : Volkman's ischaemic contracture and its relationship to fracture of the femur. J.B.J.S. Vol. 33-B, 336, 1951.

4) $T$, Campbell Thomson. : Surgical treatment of disorders of the forepart of the foot. J.B.J.S. Vol. 46-A, 1117, 1964.

5) $\mathrm{R}$, Owen. etc. : Ischaemia complicating closed tibial and fibular shaft fractures. J.B.J.S. Vol. 49-B, 268, 1967.

6) R, G, Taylor. : The treatment of claw toes by multiple transfers of flexor into extensor tendons. J.B.J.S. Vol.33-B, 539, 1951.

7) J, B. Pyper.: The flexor-extensor teasplant operation for claw toes. J.B.J.S. Vol. 40-B, $528,1958$.

8）天児民和改訂：神中整形外科手術書南山堂

9) Campbell's operative orthopaedics. 4th Ed. Mosby Co.

10）小野啓郎・他：成人の脳損傷に就ける四肢の再 建手術 整形外科 20 巻 $717 \quad 1969$.

11) Joseph E, Milgram.: Office mesures for relief of the painful foot. J.B.J.S. Vol. 46-A, 1095, 1964.

12) Dr. Cailliet. : Foor and ankle pain. F. A. Davis Co. 1968.

13) Grant, J. C.: An atlas of anatomy. Williams \& Wilkins Co. 1962.

14) Du Vries.: Surgery of the Foot. Mosby Co. 1959.

15) Lewin.: The foot and ankle. Lea \& Febiger Co. 1959.

\section{質 問}

長大整形 䅖山富太郎

長母趾屈筋腱の延長で拘縮が除去出来る症例むある と思うが，長期間経過したもので intrinsic muscles にも拘縮をきたした症例で, どの程度自動背屈（過伸 展）可能となったか。

解 答 九州厚生年金病院 杉山 栄一 MP 関節における伸展力は保たれていた。歩行の 際，問題になるのは MP 関節における屈曲力が保た れているかどうかであるが，乙の症例では幸い保たれ ているのでよい結果在得た。 屈曲力の弱い症例では腱 移行術など行ない，乙れを補なわねばならない。 